\title{
"Pensar la paz". Sobre las negociaciones entre algunos gobernadores del Tucumán y varios caciques del Chaco en la década de 1770
}

"To Think about Peace". About the Negotiations between some Governors of Tucumán and several Caciques of Chaco in the I770s

DOI: https://doi.org/I0.22380/20274688.527

Recibido: 11 de junio del 2018

Aprobado: 6 de septiembre del 2018
MARÍA LAURA CUTRERA* Instituto de Historia Argentina y Americana Dr. Emilio Ravignani, Consejo Nacional de Investigaciones Científicas y Técnicas / Facultad de Filosofía y Letras - Universidad de Buenos Aires,

Argentina mlcutrera@yahoo.com.ar

Dedico este trabajo a la memoria de Martha Bechis.

\section{R E S U M E N}

El objetivo del trabajo es reflexionar sobre negociaciones establecidas entre ellos; al la paz convenida entre algunos gobernadores del Tucumán y varios caciques autónomos del interior chaqueño -tobas, mocovíes y vilelas- a fines del siglo XVIII. Se atiende al recorrido histórico de las contexto político, económico y relacional que condujo a concebir la idea de la paz en ambas partes; y a las razones que tuvo cada una de ellas para acordarla. También se analiza críticamente el tratado firmado

* Doctora en Historia de la Universidad de San Andrés. Fue becaria posdoctoral del Conicet y actualmente es investigadora asistente del Conicet en el Instituto de Historia Argentina y Americana Dr. Emilio Ravignani. 
entre Gerónimo de Matorras y el cacique Paikín, y se contrasta lo establecido allí con los acontecimientos que lo sucedieron. Por último, se explica por qué las tratati- vas iniciadas en Salta concluyeron diez años después con la construcción de dos reducciones en el corazón del Chaco, pero en jurisdicción de Buenos Aires.

Palabras clave: paz, gobernadores del Tucumán, indios autónomos, Chaco.

\section{$\begin{array}{lllllllllllllllllll}\mathbf{A} & \mathbf{B} & \mathbf{S} & \mathbf{T} & \mathbf{R} & \mathbf{A} & \mathbf{C} & \mathbf{T}\end{array}$}

The objective of this investigation is to reflect on the peace agreed between some governors of Tucumán and several autonomous caciques of the interior of the Chaco -tobas, mocovi and vilelasat the end of the 18th century. It focuses on the historical evolution of the negotiations established between them; also on the political, economical and relational context that led to conceive the idea of peace on both sides and on the reasons that each of them had to agree on it. In addition, the treaty signed between Gerónimo de Matorras and the cacique Paikín is critically analyzed; specially what it establishes in contrast to the events that followed it. Finally, it is explained why the negotiations started in Salta and concluded ten years later, with the construction of two reductions in the heart of the Chaco, but in the jurisdiction of Buenos Aires.

Keywords: peace, governors of Tucuman, free Indians, Chaco

\section{Introducción}

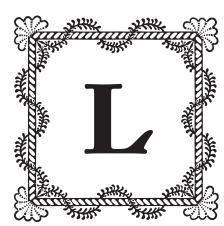

a polvareda era inconfundible. Tenía que ser el cacique Paikín. El hombre que estaba de guardia en una rama bajó a dar cuenta de las novedades al gobernador de Tucumán. Gerónimo de Matorras y los que integraban la expedición, instalados en el interior del Chaco —en Lacangayé, a más de doscientas leguas de Salta_, esperaban desde la mañana la aparición del jefe que lideraba una coalición de mocovíes y tobas.

Montado en un caballo tordillo, con un largo estoque envainado y rodeado de los suyos, Paikín se acercó a los hispanocriollos. Se apeó próximo al sitio en que se hallaba el gobernador, que se puso de pie cuando el jefe mocoví le extendió la mano. Se abrazaron. Matorras lo invitó a tomar asiento y los intérpretes dieron comienzo a su tarea. Eran casi las cinco de la tarde del 20 de julio de 1774 y empezaba así un esperado encuentro. 
Nueve días después, las conversaciones dieron lugar a la firma de un tratado a orillas del Bermejo, que no pasó inadvertido para los historiadores ocupados en los espacios fronterizos con el Chaco meridional en el siglo XviII. Están quienes, enmarcándolo en planteamientos generales, lo sitúan en el ocaso de una etapa signada por entradas y expediciones punitivas y el comienzo de otra que privilegió los parlamentos, los pactos, el comercio y la incorporación de mano de obra nativa a los establecimientos productivos que crecían en las tierras orientales del Tucumán (Gullón; Paz y Sica; Vitar). Pero hay trabajos con otro tipo de enfoques. Abelardo Levaggi, por ejemplo, compila el convenio Matorras-Paikín en un conjunto mayor de tratados, para estudiar las relaciones pacíficas "públicas", diplomáticas, establecidas entre las autoridades coloniales y los indios autónomos desde la perspectiva de la historia del derecho. Para Carlos Lázaro Ávila, dichos acuerdos marcan la consolidación de un nuevo modo de entendimiento entre las autoridades españolas y los indígenas. Su artículo indaga en los aspectos más llamativos de tales convenios en el septentrión novohispano, el Chaco y Norteamérica, a fin de dar cuenta de la actitud que tuvo la Corona con los grupos no sometidos al Imperio. El acta a que referimos es el documento escogido para explicar el caso chaqueño, previamente puesta en contexto. También reuniéndolo con otros tratados, Lidia Nacuzzi aborda el acuerdo firmado entre Matorras y Paikín. Su objetivo es reflexionar acerca del posible carácter de "dispositivos de etnificación y normalización" que tuvieron esos documentos, según plantea Guillaume Boccara. Además, la autora sostiene que son excelentes indicadores de los territorios de algunos grupos indígenas y nos permiten, con frecuencia, conocer sus desplazamientos. Por último, los tratados ponen de manifiesto los conflictos y las tensiones entre indígenas e hispanocriollos (“Tratados"). Florencia Nesis, en cambio, invita a una relectura del acta mencionada dentro de un conjunto mayor de fuentes producidas en torno a las tratativas. Esto permite, a su entender, revisar una imagen historiográficamente aceptada en que, a través de dichos convenios, los hispanocriollos habrían reforzado el dominio político y territorial sobre los indígenas ("El camino").

Todas las interpretaciones que reseńamos tienen un rasgo común. En ellas, el tratado es la instancia clave de las negociaciones. El proceso explicado queda circunscrito a la historia del encuentro y su desenlace se ubica en la firma del acta, que señala el fin del conflicto. A lo sumo, el relato se extiende por algunos años, para marcar que las promesas de Matorras permanecían incumplidas.

Nuestro objetivo es pensar la paz convenida entre algunos gobernadores del Tucumán y varios caciques autónomos del interior chaqueño, durante la 
década de 1770, para poder explicarla. El punto de partida es que el establecimiento de esa paz fue un proceso relativamente largo, que excedió temporal y problemáticamente al tratado entre Matorras y Paikín, y del cual este fue solo un momento importante. Por eso, atenderemos al recorrido de las tratativas que precedieron a su firma y mostraremos por qué el cacique mandó emisarios a pedir bautismo y reducción a Salta, en qué contexto intra e interétnico se dio tal solicitud y qué sentido tenía la concordia para las partes. Luego nos detendremos en el momento del parlamento y el análisis de la letra escrita, a la que cruzaremos con otra documentación para espiar a través de ella aquello que podía haberse conversado y no se plasmó en el papel. Aquí incluiremos algunas consideraciones antropológicas sobre la diplomacia entre los indígenas.

En un artículo a propósito de un acuerdo entre la gobernación de Buenos Aires y el cacique serrano Cangapol, Martha Bechis sostiene que el análisis histórico de esos documentos requiere, entre otras cosas, preguntarse sobre su efectividad, si sirvieron para algo. Ello implica un cuidadoso examen de su a posteriori. Así, observaremos qué ocurrió después, contrastando lo establecido en el acta con los acontecimientos que la sucedieron. Además, ese tiempo estuvo cruzado por otras reuniones que siguieron construyendo y definiendo consensos nuevos.

Este trabajo se inicia en los albores de la década de 1770 — aunque se remonta algo atrás en el tiempo-, cuando las autoridades del Tucumán y una alianza toba-mocoví, liderada por el cacique Paikín, concibieron la paz como modo de relacionarse; y se cierra en febrero de 178I con la fundación de San Bernardo el Vértiz y Nuestra Señora de los Dolores y Santiago de Lacangayé, dos pueblos de tobas y mocovíes, respectivamenter. Ambos se instalaron en el corazón del Chaco y más cerca de Corrientes que de la capital tucumana, de manera que también explicaremos por qué las tratativas iniciadas en esta última culminaron con el envío de una expedición que erigió dos reducciones en jurisdicción de Buenos Aires. Para ello, incluiremos otros espacios fronterizos del Chaco meridional — Santa Fe, Corrientes y, en menor medida, Asunción- que permiten dar cuenta de lo que sucedía en Salta. Además, mostraremos que el significado que cada una de las partes otorgó a los pueblos en cuestión también explica el desplazamiento geográfico.

I Cabe advertir que durante el periodo estudiado tuvo lugar la creación del Virreinato del Río de la Plata. Sin embargo, ello no parece haber incidido en el desarrollo del proceso analizado. 
En el texto antes mencionado, Bechis sugiere que el establecimiento de la paz debía ser una opción posible para los involucrados en ella o, al menos, para el sector de la sociedad que tuviera el poder de imponérselo al resto. Esto planteaba un problema adicional entre los indígenas, dice. Aquí lo más difícil era construir consensos internos, ya que sus autoridades tenían que persuadir a los suyos sin que pudiera prevalecer su voluntad sobre la de sus pares o seguidores. La autora advierte que esta segmentación también debemos buscarla entre los hispanocriollos. Solo que la encontraremos con otra forma. La hallaremos en la existencia de distintas facciones y dentro de estas: entre los capitulares, los virreyes, los gobernadores, los oidores, los oficiales militares y los religiosos. La diferencia estaba en que algunos de ellos tenían la posibilidad de tomar decisiones y, sobre todo, de obligar a los demás (Benchis). Pero, además, la veremos entre las ciudades involucradas en la paz con la coalición tobamocoví. Santa Fe y Buenos Aires tuvieron otros problemas y otros vínculos con los mismos indios; por eso, su postura frente al tratado y la concreción de las promesas hechas en ocasiones sería diferente a las de Salta, Jujuy o Tucumán.

En su devenir, las negociaciones tomaron caminos que parecían conducir al fin planeado. No obstante, hubo circunstancias que los alteraron. La muerte de Paikín o la de Matorras son algunos ejemplos. Así que diremos, por último, que el proceso que pensamos no fue lineal.

\section{La historia que originó la paz como idea}

\section{Los hispanocriollos}

Al este de las ciudades que los españoles fundaron en la gobernación del Tucumán y de los espacios ocupados en sus inmediaciones, había grupos indígenas con los que se establecieron relaciones oscilantes entre la convivencia pacífica y el enfrentamiento. Los más alejados, habitantes del interior chaqueño, eran los guaycurúes, entre los que se contaban los tobas, los mocovíes y los abipones.

Durante el siglo XVII, sus incursiones se hicieron sentir con violencia. Como llegaron hasta muy cerca de Salta y Jujuy, los españoles elaboraron una estrategia que combinó modalidades defensivas y ofensivas. Así, construyeron fuertes-presidios en los que se congregaban soldados pagados sostenidos por los cabildos, otros mantenidos por la gobernación o las autoridades virreinales y 
presidiarios. En época de lluvias, cuando los ataques indígenas recrudecían, esos hombres eran asistidos por milicianos de las ciudades. En 1739, se creó el cuerpo de "partidarios": una fuerza rentada, dedicada exclusivamente al cuidado de la frontera, que pretendía disminuir el peso de la defensa a los particulares. Sin embargo, el objetivo no siempre se logró: el ramo de sisa, la fuente proveedora de recursos, resultaba insuficiente para cubrir tales gastos. Simultáneamente, se llevaron a cabo "entradas" al Chaco que procuraban intimidar a los indios ante la imagen de las fuerzas españolas y alejarlos de los espacios ocupados por los hispanocriollos, pero los beneficios obtenidos fueron pocos.

Las reducciones también resultaron piezas clave para la penetración española en territorio indígena. Se erigían cerca de los fuertes - o viceversa- que vigilaban a los indios asentados en ellas, a la vez que las protegían o socorrían si sufrían alguna agresión. Además, los neófitos podían recibir armas e incluso adiestramiento militar para contribuir a la defensa fronteriza y sumarse a las incursiones al Chaco. La primera fue San Esteban de Miraflores, en jurisdicción de Salta. En 1735 se edificó San José de Petacas, en términos de Santiago del Estero. A ellas siguieron San Juan Bautista de Balbuena y Nuestra Señora del Buen Consejo de Ortega, también en Salta; San Ignacio de indios tobas, en Jujuy; Nuestra Señora de la Concepción, de abipones, en Santiago; y Nuestra Señora del Pilar de Macapillo, en jurisdicción de San Miguel de Tucumán. Pero, a comienzos de I767, se produjo la expulsión de los jesuitas. El hecho alteraba las relaciones interétnicas, ya que estos religiosos habían contribuido a la construcción de vínculos armónicos con los indios. Por eso, las misiones no desaparecieron: quedaron en manos de administradores civiles, que se encargarían de sus "temporalidades", mientras la instrucción religiosa se confiaba a padres franciscanos.

Para entonces, la minería potosina se recuperaba y demandaba vacas y mulas que necesitaban pasturas, empujando la ocupación hacia el este y dando lugar a la instalación de pequeños productores y a la proliferación de nuevas estancias ganaderas (Mata). Como el espacio fronterizo gozaba de cierta tranquilidad, fuertes y reducciones quedaban atrás de los particulares. La dinámica expansiva recibía, también, el impulso dado por el incremento de las exportaciones de derivados del vacuno en Buenos Aires, ya que la zona se afirmaba progresivamente como intermediaria entre aquel puerto y Potosí.

Sin embargo, las fronteras habían avanzado poco y España necesitaba concentrarse en la defensa de sus dominios contra enemigos externos. Así, los recursos destinados a los fuertes no podían continuar multiplicándose y debía intentarse una estrategia alternativa a las "entradas". Fue ganando lugar la idea 
de pacificación de los indios, que no relegaba las intenciones evangelizadoras. Ello encontraba un marco favorable en la política indígena impulsada por los Borbones: las campañas "punitivas" debían dejar lugar a la vía diplomática (Weber, "Borbones”; Weber, Bárbaros). De esta manera, podría incorporarse a los aborígenes a la defensa de las fronteras y también al engranaje productivo. Simultáneamente, sería posible la tranquilidad de hacendados y estancieros y el control de los circuitos mercantiles².

En este clima, el Consejo de Indias analizó un proyecto presentado al virrey del Perú por un comerciante español establecido en Buenos Aires. Se trataba de Gerónimo de Matorras, a quien se aprobó un plan de "reducción y población del Chaco". Su propuesta tomó forma de contrato con la Corona cuando aquel se comprometió a cumplir una serie de condiciones, a cambio del nombramiento como gobernador de Tucumán (Gullón 80). Pero no pudo ocupar su cargo de inmediato. Conflictos con su par de Buenos Aires, Francisco de Paula Bucarelli y Ursúa, lo llevaron a comparecer ante la Real Audiencia de Lima. Asumió la gobernación en 1769 y se desempeñó en el puesto hasta su muerte (Gullón 8I-82).

Matorras estaba convencido de que la guerra con los indígenas era simultáneamente inútil y contraproducente. Sostenía que la paz era condición ineludible para adelantar la frontera, pero también para asegurar la ocupación existente, alivianar el peligro de los ataques guaycurúes en las rutas comerciales y abrir otros caminos a la circulación. A comienzos de $\mathbf{1 7 7 2}$, un año después de haber visitado las misiones lindantes con el Chaco, proponía la creación de cuatro reducciones nuevas. Dos de ellas debían reunir a los mocovíes — que se habían acercado a solicitárselo- en las márgenes del río Salado. Eso traería

[...] las ventajas de hacer comunicable en derechura el camino fertilizando las tierras desde Santiago del Estero a la ciudad de Santa Fe de Buenos Aires [...], y asegura la Frontera del Tío de la jurisdicción de Córdoba y [...] servirá de mucho estímulo para que a su imitación vengan otros muchos indios a poblarse en los mismos parajes [...] también se

2 Claro que esta forma de pensar podía chocar con las condiciones y los intereses locales. En ocasiones, las intenciones de la Corona se diluían en el devenir de cartas, solicitudes y reclamos, cuando no acababan perdiéndose a manos de los hacendados, comandantes militares o administradores de las reducciones. Los cabildos eran sedes de reuniones en las que se debatían propuestas sobre el trato que debía dispensarse a los indios: sobre la utilidad de las campañas de escarmiento, sobre la conveniencia de darlos en encomienda o trasladarlos a zonas próximas a centros mineros para emplearlos como mano de obra, entre otras. Pese a ello, la idea de la paz iba ganando adeptos. 
resultará la seguridad de todas las campañas nombradas Los Porongos, pues cortado aquel paso se cortarán las muchas invasiones que hacen los indios en las fronteras de Córdoba [...]

Podía construirse otra misión en un sitio nombrado San Barthelemí, también a orillas del Salado, en las inmediaciones de San José de Petacas. Por último, debía ubicarse en pueblo a "[...] más de cuatrocientos indios de armas de la nación mataguaya con sus familias [...]”, en la frontera confinante al curato de Humahuaca (AGN, T, s. IX 37-6-2).

Mientras Matorras escribía la carta-informe que citamos, se presentó en Salta una comitiva de tobas y mocovíes aliados, encabezada por el hijo de Paikín. El momento era propicio: la paz tomaba cuerpo entre las ideas de algunos hispanocriollos pero, sobre todo, en uno de sus hombres influyentes.

\section{Los indígenas}

En el periodo que estudiamos, el Chaco era un enorme espacio delimitado por los asentamientos españoles pertenecientes a la Audiencia de Charcas, la gobernación del Tucumán, del Plata y la gobernación del Paraguay. Estaba habitado por varios grupos indígenas, entre los que se encontraban los ya mencionados.

Los tobas residían a lo largo de los ríos Pilcomayo y Bermejo, muy cerca de los mocovíes. Los campamentos centrales de estos últimos se ubicaban entre dichos cursos de agua, en la zona occidental del Chaco, aunque se desplazaban a lo largo de los ríos, entre Salta y el sistema fluvial Paraná-Paraguay (Nesis, "El camino"). Entre tobas y mocovíes hubo, en general, buenas relaciones. Es frecuente encontrar caciques de ambos grupos formando alianzas relativamente estables. A mediados del siglo Xvir, penetraron desde el Bermejo hacia el sur y emprendieron correrías de saqueo a través de Salta, Jujuy, San Miguel de Tucumán, Esteco, Santiago del Estero y Córdoba (Kersten 54). Los abipones, entretanto, habitaban la zona central y oriental del río Bermejo (Lucaioli, Abipones). En todos los casos, los grandes ríos - Salado, Pilcomayo, Bermejo y Paraná- parecen haber funcionado como límites con vecinos "no amigos", demarcando amplias regiones por las que estos grupos se desplazaban siguiendo la disponibilidad espaciotemporal de recursos (Nacuzzi, "Los grupos").

Entre junio y agosto de I7Io se produjo una de las más grandes "entradas" al Chaco. El gobernador de Tucumán —Esteban de Urízar y Arespacochaga—realizó 
la primera de sus campañas. La presión de sus tropas obligó al desplazamiento de abipones y mocovíes. Los segundos se corrieron hacia tierras de los primeros, iniciándose así una convivencia estrecha entre ellos y la profundización de los vínculos con los hispanocriollos de Santa Fe (Lucaioli, Abipones). Transacciones comerciales más asiduas, trabajo indígena en establecimientos productivos o ataques aborígenes a estos fueron algunas de sus manifestaciones. El periodo comprendido entre 1720 y 1740 estuvo marcado por tales conflictos (Lucaioli, Abipones; Lucaioli y Nesis, "El ganado").

Igual que en otras partes del imperio, las misiones fueron una estrategia para asegurar los espacios ocupados. Santa Fe dio el puntapié inicial. En I743 surgió San Javier y veintiún años después, San Pedro, ambas para grupos mocovíes. Para los abipones se fundó San Jerónimo, en 1748. A estos últimos también se los redujo en otras ciudades: Nuestra Señora de la Concepción, en 1749, en jurisdicción de Santiago; San Fernando, en términos de Corrientes; y Timbó, en I763, en Asunción.

La posibilidad de incorporarse a una reducción suponía beneficios que los indios sopesaron. Las misiones eran espacios medianamente vigilados, donde podían construirse corrales para reunir las reses y postergar el intercambio del ganado. En parte, permitían compatibilizar la posesión de sitios de pastoreo relativamente permanentes con la movilidad que todavía conservaban los indígenas. Además, en el momento de la fundación se les entregaban regalos y donaciones, posteriormente complementados con envíos puntuales de carne vacuna y productos que contribuyeran a su subsistencia (Lucaioli, "Alianzas"). A las reseñadas, se sumaron la simplificación del acceso a bienes hispanocriollos —en parte, gracias al establecimiento de intercambios más seguros y duraderos-y el tejido de nuevas relaciones interétnicas. Podían ser, también, un refugio ante conflictos con otros grupos (Lucaioli, Abipones). Finalmente, lejos de suponer una sedentarización y un adoctrinamiento rigurosos, se iba y venía entre ellas y el interior chaqueño sin cortar los vínculos con parientes, aliados o amigos que permanecieran autónomos (Lucaioli, "Alianzas"). La estadía en las reducciones se incorporó a las prácticas sociales indígenas, junto con la cacería o la recolección, y el abandono formó parte de los movimientos estacionales (Mata).

Sin embargo, las negociaciones y la vida en la misión podían generar rispideces entre quienes se incorporaban a estos pueblos y quienes escogían no hacerlo. Los enfrentamientos entre tobas-mocovíes y abipones eran previos a la experiencia reduccional, pero los pueblos fueron un blanco atractivo para su profundización. La existencia de parientes entre los reducidos ayudaba a los 
grupos del interior chaqueño a obtener información sobre los adversarios y mejoraba la logística de las incursiones. De hecho, algunos de estos se sumaban a las filas de los indios libres para participar del asalto. Las represalias no se hacían esperar, y alimentaban un ciclo de venganzas en el que también intervenían las tropas hispanocriollas.

Cuando el rey de España expulsó a los jesuitas de sus dominios, los conflictos entre los indígenas autónomos y los asentados en la frontera santafesina se agudizaron. A los problemas existentes se acoplaron las agresiones entre reducciones, apoyadas — cuando no instigadas - por los grupos autónomos. Los bienes robados en las misiones próximas a una ciudad eran fácilmente vendidos en otra.

Suponemos que el acercamiento de Paikín a Salta tuvo que ver con esto. Contar con parientes reducidos en Santa Fe — como el cacique Domingo Navedagnac, su primo, corregidor de San Javier- permitiría el abastecimiento de ganado, bienes y cautivos a través de los asaltos a los pueblos abipones. Una conveniente paz con Salta posibilitaba su ubicación en aquella plaza, a la vez que proveerse de alimentos, armas, cabalgaduras y hasta hombres para socorro militar. En ese recorrido, el control de ciertos espacios no era de importancia menor y, tal vez por ello, durante las negociaciones que analizaremos, tobas y mocovíes insistieron en que las reducciones se hicieran en sus tierras.

\section{La construcción del consenso}

Un día de marzo de 1773, el padre Antonio Lapa recibió una comitiva encabezada por Pasampaikín — hijo de Paikín—en la reducción de Macapillo. Poco después, el protector general de naturales - Isidoro de la Plaza— notificó a Matorras que el cacique mocoví solicitaba bautismo y reducción, y que por estar muy anciano esperaba que el gobernador pasara en persona a su tierra, para ratificarle su voluntad y establecer un sitio para su pueblo. Los emisarios permanecerían como rehenes y comenzaría un largo recorrido de reuniones, acuerdos e informes en que se iría construyendo un consenso que marcaría cómo proceder a continuación ${ }^{3}$.

3 Bechis afirma que desde la mera concepción de la paz por una de las partes en contacto, se fueron diseñando lo modos y los contenidos de las negociaciones. Estas comenzaron con ceremonias previas - “parlas”, “juntas de indios”, “juntas de guerra”-, como grados menores o instrumentos del consenso que definieron los términos en que podía pensarse una relación diferente. Así se dibujaron 
Al mes siguiente, se trató en el Cabildo de Salta sobre la llegada de los jefes y sus propuestas. Los asistentes acordaron cuestiones relativas al vestuario y el agasajo de los huéspedes y los bienes que se mandarían a Paikín. Pero lo más importante fue la aprobación de una campaña al Chaco, conducida por Matorras, para entrevistarse con aquel. Se dispuso también que si Paikín y los suyos deseaban ponerse en reducción, se les señalaría el sitio llamado San Barthelemí, ubicado a orillas del río Salado y entre las reducciones de Macapillo y Petacas ${ }^{4}$. Por último, se indicaba que, para suplir los gastos de la expedición y la edificación del pueblo, se utilizaran i2.00o pesos ofrecidos por Matorras a la Corona y que constaban en la Real Contrata. Cuando no resultaran suficientes, podrían pedírsele los auxilios necesarios al virrey. Matorras se comprometió a mantenerlo informado, igual que al gobernador de Buenos Aires - a cuyo cargo se hallaban los asuntos de la excursión a los países del Gran Chaco-.

El I. ${ }^{\circ}$ de junio de 1774 se realizó una junta de guerra en el fuerte de San Fernando del Río del Valle, donde se pautaron cuestiones relativas a la marcha. Los asistentes coincidieron en que irían al encuentro de Paikín, a quien se establecería en la reducción de Santa Rosa de Lima, y que, de no ser posible, el gobernador destinaría otro paraje para ello. La expedición también se proponía llegar hasta Corrientes, con intenciones de explorar el Chaco. Se nombró comandante general de esta a Francisco Gabino Arias. Junto a ellos, iban los religiosos Antonio Lapa y Lorenzo Suárez de Cantillana. Una semana después, partieron.

Ya entrada la marcha, Matorras tuvo oportunidad de entrevistarse con una hermana de Paikín, casada con un jefe toba. En el encuentro aparecieron gestos que volverían a repetirse: el apeo y el abrazo con los caciques, que sellaba el acercamiento, y los saludos siempre descritos como afectuosos. Pero también los regalos, igual de importantes que las demostraciones de estima o simpatías.

los puntos de encuentro, que confluyeron en un consenso común. De esta manera, iba diseñándose el acuerdo escrito. Luego, el ritual - la firma misma del documento, la entrega de obsequios, los abrazos, etcétera - transformaba aquella narración en una nueva realidad social.

4 A finales de diciembre, se edificó allí una nueva reducción. Recibió el nombre de Santa Rosa de Lima y albergó núcleos de vilelas que solicitaban pueblo desde tiempo atrás.

5 Los regalos iniciaban una relación de dependencia recíproca entre el dador y su receptor, y comportaban ventajas y obligaciones para las partes. Quien recibía y aceptaba un obsequio, contraía una suerte de deuda con aquel que lo daba, hasta tanto devolviera lo donado, sin que ello implicara su anulación con un presente idéntico. El dominio de lo regalable desbordaba ampliamente lo material — podía ser una danza, un acto de magia, un ser humano, el apoyo en un conflicto o en una guerra-, siendo todo aquello cuya distribución fuera posible, tuviera sentido y pudiera crear obligaciones en el otro (Godelier, El enigma). 
Después de obsequiarlos y parlamentar con ellos, el cuñado del líder mocoví y dos indios resolvieron sumarse a la expedición. Lo hacían para guiarla por tierras poco conocidas por los hispanocriollos y brindarles protección, evitando la circulación por espacios en los que pudieran sentirse inseguros o ser interceptados por grupos hostiles. Por otra parte, se mandó a dos indios que avisaran a Paikín y a Lachiriquín que el gobernador venía a visitarlos. El envío de chasques en a mbas direcciones, que se adelantaban llevando y trayendo noticias, permitía cuidar el marco protocolar en que los encuentros debían producirse, atendiendo a la "presentación del yo" desde lo visual y también al reconocimiento de la otra parte. Los emisarios regresaron al día siguiente y comunicaron que el jefe mocoví se había internado para el lado de Corrientes, pero que el otro cacique se acercaba con alguna familia - entre quienes se contaban una hija y un hijo del líder de la coalición-.

Lachiriquín era mocoví. Se trataba de "[...] uno de los caciques que han hecho más estragos en las fronteras por su numerosa y guerrera nación [...]" (Brizuela I4). Por eso, el encuentro con él estuvo rodeado de atenciones especiales y los presentes fueron diferentes de los que recibieran otros indios. Matorras dio a Lachiriquín varias baraterías, carne y comestibles para él y para repartir con sus acompañantes, pero distinguió al jefe obsequiándolo con un vestuario completo y un bastón ${ }^{6}$. Lachiriquín informó que los toldos de Paikín se hallaban a dos jornadas de distancia y ofreció acompañarlos hasta ese destino (AGN, T, S. IX 37-6-2).

El in de julio llegaron a Lacangayé. Un indio ladino comunicó que Paikín vendría a encontrarlos al día siguiente. Matorras puso en marcha los preparativos para su recepción. Cuando a las dieciséis horas del 20 de julio arribó el chasque,

6 La provisión de alimentos a los aborígenes era prácticamente cotidiana y en las fuentes parece diferenciarse de los regalos. En principio, porque estos tenían destinatarios específicos. El regalo se individualizaba, mientras que el abastecimiento de comida estaba destinado al conjunto. Pero, además, el suministro de víveres parece responder a una lógica distinta. Era esperado, sobre todo de alguien que se presentaba con la dignidad con que lo hacía Matorras o que como él venía en nombre del rey de España, cuya grandeza no podía dejar lugar a dudas. Dar era mostrar que se era rico, que se tenía aquello que al otro le faltaba y que ese bien se podía repartir. Ello permitiría reconocer en Matorras a un hombre generoso y un aliado en quien se podía confiar. La generosidad era un valor positivo entre los indios, era la esencia de la bondad, y la tacañería, un vicio despreciado. Cuanto más importante fuera la posición social del individuo, más desearía brillar por su prodigalidad. Así que, a más alto rango, mayor era la obligación de ser desprendido. Por ello se explica, a su vez, que los caciques entregaran a los suyos los dones recibidos. Por último, Matorras entraba en el Chaco durante el invierno, que era la época de seca y hambruna. 
avisando que ya estaba cerca, mandó a tocar la caja, puso a toda la gente sobre las armas, se vistió de gala y despachó al comandante con varios oficiales, al indio Colompotop — cacique gobernador de la reducción de Macapillo- y la bandera con las reales armas de España, para que fueran a buscarlo.

El líder mocoví llegó al campamento una hora después. Matorras le dio a entender por medio de los lenguaraces que venía de paz. Luego le propuso que, para cubrir su desnudez, admitiera el vestuario que le traía dispuesto. Cuando Paikín iba a retirarse, hizo un último gesto: volvió a abrazarlo y "[...] le presentó al despedirse un bastón con puño dorado y cinta [...]” (AGN, T, s. IX 37-6-2). Este obsequio traducía la jerarquía que Matorras podía percibir en la coalición de indios: Blas de Brizuela — que escribió el diario de la expedición-y el propio gobernador refieren a Paikín con el calificativo de "primer caporal” (Brizuela 19). Al mismo tiempo, reforzaba esa jerarquía identificándolo como interlocutor destacado entre una pluralidad de jefes. Pero, además, los presentes convertían a sus dadores y a sus receptores en socios ${ }^{7}$. Para terminar de impresionarlos, Matorras invitó a los jefes y sus seguidores a que vieran el ejercicio de armas. A toque de caja, el cabo subalterno de los partidarios, Francisco Triviños, dio comienzo a la demostración.

Aquí es preciso hacer una advertencia. Cuando se sigue el relato de las fuentes, el clima en que transcurren las negociaciones parece desprovisto de tensión. Entonces, es significativo que tanto el diario como los autos expresen, sin mayores explicaciones, que "[...] pidió Paikín al Sr. Gobernador por medio de sus intérpretes que le dejase a Don Francisco Triviños con algunas armas para que le enseñase el ejercicio [...]” (AGN, T, s. IX 37-6-2). ¿Por qué quería las armas Paikín y para qué pretendía aprender a usarlas? La bitácora de la campaña y los informes de Matorras hablan de la voluntad indígena de hacer la paz y establecerse en reducción, pero omiten cuestiones relativas al enfrentamiento entre Paikín e Ychoalay, cacique gobernador de San Jerónimo, también conocido como José Benavídez. Matorras guardaba silencio sobre uno de los móviles fundamentales para explicar el acercamiento de los indios a Salta.

El gobernador de Tucumán se dispuso a intervenir para poner fin a los conflictos. Despachó chasques a las ciudades de Santa Fe y Corrientes, para que

7 Al tiempo que edificaban un nuevo vínculo entre los hombres, los obsequios lo visibilizaban para los actores y para quienes miramos de cerca o de lejos, en el espacio y en el tiempo (Bechis, "Pensar"). La fuerza del objeto reside en que materializa lo invisible, representa lo irrepresentable (Godelier, Elenigma). 
se ocuparan de pacificar y contener a los abipones y procuraran la reconciliación entre estos y la alianza liderada por Paikín (Cervera). El Cabildo de Santa Fe se dirigió al cacique de San Fernando — la reducción abipona de Corrientes-y a Benavídez, para pedir la concertación entre ellos y la coalición toba-mocoví. Además, se convocó a Navedagnac para que, como primo de Paikín, trabajara por la paz. Por otra parte, el alcalde segundo fue comisionado para dialogar con los caciques de San Pedro y San Javier. Como Santa Fe no podía hacer mucho más por la conciliación entre los indios, el Cabildo respondió a Arias que procurara reducir a Paikín y agregarlo al pueblo de Santa Rosa de Lima. De esa forma, lo acercarían a la frontera Tucumana y lo alejarían de Benavídez, poniendo fin a las hostilidades.

\section{Parlamento y tratado}

El 22 de julio, la expedición, ahora guiada por Paikín y su séquito, levantó la carga y caminó hasta un lugar al que se llamó Potreros de San Bernardo. Allí se celebró un parlamento muy formal. Concurrieron algunos de los integrantes de la campaña, encabezados por Matorras, y varios caciques mocovíes y tobas.

Los parlamentos eran ceremonias de paz del más alto nivel ritual. Después de las entregas de obsequios, las discusiones y los gestos, solía seguirse la firma de un tratado, en cuyas actas aparecían las cuestiones que las partes pudieran acordar - aunque no todas-. Se narraban los derechos y los deberes que las involucraban y se exponía aquello que unos y otros estuvieran dispuestos a exigir y a conceder, en el presente y en el futuro, de acuerdo con su situación y la situación del otro, tal y como se presentara cada uno de los contratantes (Bechis, "Pensar"). Con el tiempo, las actas fueron adquiriendo una forma repetida, y se expresaron casi invariablemente las "conquistas" españolas y las "concesiones" indígenas. Nuestro caso no fue la excepción. El gobernador y sus oficiales firmaron su consentimiento y los caciques dieron el propio por sí y en nombre de los demás.

Florencia Roulet observa que, como documentos históricos, los tratados no tuvieron versión en lengua indígena. Ello implica que no podemos comparar lo escrito con las interpretaciones que los firmantes pudieron hacer sobre lo acordado en el parlamento. La autora sostiene que la pluma de quien escribe no recoge todas las palabras de quienes hablaron. Y como en el siglo XVIII los caciques no tenían modo de verificar por sí mismos o con secretarios letrados 
lo que efectivamente decían los documentos, al ratificarlos demostraban la confianza en la buena fe de sus contrapartes.

En el acta firmada por Matorras y Paikín se acordó, en primer lugar, que se dejaría a los indios en posesión de sus tierras. En segundo término, se disponía que no se les daría el trato de esclavos ni se los entregaría en encomienda. Luego, se establecía la asignación de curas doctrineros y lenguaraces, que los instruirían en la fe, y de maestros que enseñaran la lengua española y la lectura y escritura a quienes lo desearan. En el cuarto punto se los invitaba a sumarse a la misión de Santa Rosa de Lima; pero si los indios pidieran otra, decía el artículo a continuación, se les daría "[...] en uno de los parajes que han señalado en estos lugares, o en el que el Sr. Gobernador del Tucumán tuviere por más conveniente [...]”. El sexto artículo da cuenta del gusto con que los indígenas recibieron los obsequios que se les hicieron, la amabilidad con que Matorras y su comitiva habían actuado, y que esperaban se ejecutara lo propio en adelante (ATJ, leg. I515, año I77ı. Énfasis añadido) ${ }^{8}$.

Después las actas cambian casi abruptamente de tema. La cláusula siguiente menciona, por segunda vez en un contexto documental que refiere muy poco a ello, el conflicto con Ychoalay y sus seguidores. Significativamente, aquí los españoles parecen no asumir compromisos. Se informa que Matorras exhortó a los indios a que "[...] deponiendo sus sentimientos se establezcan paces entre unos y otros [...]”; y mandó chasque al gobernador de Buenos Aires y a los cabildos de Santa Fe y Corrientes, instándoles "[...] a que contengan al mencionado Benavídez y demás abipones [...]” (ATJ, leg. 1515, año I77I, sin folio).

En el octavo acápite, los indios aceptaban convertirse en vasallos del rey de España y obedecer a sus órdenes y autoridades, observando el debido cumplimiento de las leyes; pero confiaban en que también a ellos les serían "[...] cumplidos y guardados todos aquellos fueros y privilegios que están concedidos [...] a todos los indios naturales de ellas [...]”. En contrapartida, el capítulo siguiente los obligaba a acudir a los protectores

[...] siempre que tuviesen alguna queja o agravio de los españoles o de los indios puestos en las reducciones de la dicha provincia [...] sin que puedan de otro modo hostilizar, hacer guerra ofensiva, ni defensiva, en las fronteras ni tampoco en las reducciones [...]

8 Nótese la incongruencia existente entre el año en el que fue producida la fuente (1774) y el de I77I, al que refiere la cita. Debemos advertir que, lejos de tratarse de un error, hemos citado el documento respetando estrictamente la nomenclatura del catálogo. 
Luego, el gobernador se obligaba a interceder por ellos ante el rey para colocarlos bajo su amparo y ser aceptados como vasallos, a la vez que a mediar entre ellos, el virrey y sus audiencias (ATJ, leg. 15I5, año I77I).

La última cláusula vuelve implícitamente sobre el conflicto con los abipones y la reacción de Matorras:

En este estado - dice el tratado- pidieron y suplicaron dichos caciques al Sr. Gobernador que les mandase dar algunas armas como pistolas, espadas, machetes y lanzas para defenderse de sus enemigos y que igualmente con ellas servirían en cuanto se les mandase [...] (АTJ, leg. I515, año I77I, sin folio).

Pero Matorras se los negó, no sin prometerles atender a su pretensión cuando hubieran dado "[...] pruebas de su fiel vasallaje al Rey [...]" (ATJ, leg. I5I5, año I77I, sin folio). Las paces se sellaron nuevamente con abrazos.

Es importante observar algunas cuestiones antes de continuar. En principio, el tratado tenía un contenido que no se planteaba expresamente. Roulet asegura que la pluma del escribiente distorsiona los hechos, de varias maneras. La pluma omite, dice la autora, oculta y deforma. Se omiten, por ejemplo, compromisos asumidos por funcionarios españoles, sobre todo cuando estos no saben si contarán con el aval de sus superiores. Hay promesas verbales hechas ante testigos o en privado que las actas no recogen, pero a las que la tradición oral indígena les otorgaba carácter vinculante (Roulet 317-318). Cuando Brizuela reseña el acuerdo en el diario de la expedición, cuenta que Matorras intervino personalmente para que culminaran los conflictos entre abipones y mocovíes, y garantizó que se interesaría por que los seguidores de Paikín "[...] fuesen desagraviados de los muchos perjuicios que habían recibido de dichos abipones, devolviéndoles los caballos y yeguas que les tenían quitados [...]" (Brizuela 23). En el tratado, el gobernador no asume compromisos con los indios. Pero en la fuente producida por Brizuela se advierte cierta voluntad de elogiar la figura del gobernador y su desempeño para llevar a buen fin las negociaciones con el cacique mocoví, que lo conducen a dar cuenta de gestos y actitudes callados por las actas.

El acuerdo omitió más que esto. Al día siguiente de la firma, Matorras convocó a sus oficiales a una junta de guerra. Se debatiría sobre las posibilidades de que la campaña siguiera hasta la ciudad de Corrientes. Y decidieron no hacerlo. Entre las razones consideradas, 
[...] la mayor dificultad [...] consiste en la bárbara y tenaz pretensión de los referidos caciques a que los auxiliemos y demos armas para continuar en sus guerras y peleonas en que se hallan encarnizados con los indios de la nación abipona y especialmente contra el cacique José Benavídez [...] (AGN, T, S. IX 37-6-2)

Nada decía el tratado sobre una posible contribución militar, pero los indios la reclamaban. En su insistencia es posible entrever que el tema había formado parte de las discusiones del parlamento o de alguna conversación privada. Debe advertirse aquí que, aun cuando quien escribe es el propio Matorras, las condiciones de producción del documento son diferentes a las de la redacción del tratado, como también lo es el tipo de cuestiones de que dan cuenta uno y otro. Por esta razón, los autos proporcionan información que en el acta no se consigna. Mientras que en ella deben mostrarse los logros del gobernador en la pacificación de los grupos tobas-mocovíes y el cumplimiento de la Real Contrata, en los autos Matorras notifica al virrey de las razones por las que la campaña no cumplió su cometido de llegar hasta Corrientes y explorar el Chaco. Es en esta última instancia de redacción de aquello que se comunica que el gobernador referirá a la tenacidad del pedido de ayuda militar y armamento efectuado por los indios, lo que nos permite entrever las elusiones del tratado.

Las actas del Cabildo de Santa Fe también son elocuentes. En ellas se informa haber debatido un pliego enviado por Matorras y Arias el 28 de julio de 1774 , en que el gobernador de Tucumán explicaba que los indios "[...] se han empeñado, a que se les auxilie en la guerra que mantienen contra Joseph Benavídez y la demás nación abipona establecida en la Reducción nombrada San Jerónimo de esta jurisdicción [...]” (AGPSF, ACSF, I8/8/1774). De seguir el camino hasta Corrientes, podía esperarse que los caciques quisieran acompañar a sus nuevos aliados. Matorras reconoce que eso hubiera resultado peligrosísimo, porque si los indígenas perseveraban en su empeño de atacar San Jerónimo, ellos no hubieran podido impedirlo y tampoco participar, asestando un golpe fatal a las paces alcanzadas. Así, la carta que los responsables de la campaña y las negociaciones mandan a Santa Fe explicita la crítica disyuntiva en que se encuentran los hispanocriollos una vez celebrado el acuerdo y de cara a la primera oportunidad de ser consecuentes con lo pactado. Los indios le piden armamento y se empeñan en que aquellos los auxilien contra Benavídez, sin que el gobernador pueda negarse de forma contundente. El contenido de la nota a que se refieren las actas capitulares no evidencia únicamente lo conversado en aquella 
instancia, sino las propias debilidades de Arias y Matorras. Estos necesitan que, desde dicha ciudad, se actúe en la persuasión de las agrupaciones reducidas en su frontera, porque les resulta muy difícil convencer a Paikín de poner fin a los enfrentamientos con Ychoalay. Apelarán al gobierno santafesino, dilatarán la solicitud de armas y evadirán la demanda de ayuda militar, emprendiendo el regreso a Salta. Por otra parte, el documento también expone la propia posición de Santa Fe ante al conflicto entre abipones y mocovíes. La discusión a que da lugar la misiva de los expedicionarios no constituye un evento aislado en este tipo de reuniones. Los conflictos entre dichas agrupaciones — reducidas o noeran una de las principales causas de intranquilidad en aquella jurisdicción. De esta manera, el registro escrito del pliego recibido desde Lacangayé contribuye a relativizar los logros del gobernador de Tucumán, exaltados en el tratado, y pone de relieve la magnitud, la complejidad y las implicaciones de la guerra entre los indígenas mencionados y lo difícil que podía resultar acabar con ella.

La pluma de quien escribe también oculta. Esconde los motivos que condujeron a los indígenas a mandar emisarios a la capital tucumana. Plantear tal conexión causal quitaba mérito a Matorras. El texto del tratado tampoco menciona la poca disposición de Paikín al acercamiento con sus enemigos. Así lo informaron Matorras y Arias: “[...] parece que no está aún convencido dicho cacique Paikín de establecer las paces con los caciques de los pueblos de San Jerónimo y San Fernando de la nación abipona [...]" (AGPSF ACSF, 23/8/1774).

Por último, la pluma deforma. El acta muestra a un Matorras que negoció hábilmente y que sin muchos impedimentos consiguió la pacificación de los bravísimos tobas y mocovíes. De paso, y también gracias a su destreza diplomática, se pondría fin a los conflictos ancestrales que tenían con los abipones, que azotaban de manera constante la frontera santafesina. Por otra parte, Paikín era presentado como un hombre "[...] de buena presencia y belicoso genio, venerado por Primer Caporal [...] y de bastante comprensión y legalidad [...]" (AHPJ, LC, CRR, t. XXVIII, f. I2I r.). Las últimas características aluden al cacique que recibe el bastón, que es vestido, que en las fuentes producidas por los expedicionarios escucha más de lo que dice y cede más de lo que impone. No obstante, el cruce con otra documentación muestra un Paikín distinto, que reclama auxilio militar y, pese a las exhortaciones de Matorras, no se manifiesta dispuesto a terminar su enfrentamiento con Benavídez.

Un 3I de agosto se levantaron los campamentos y la expedición emprendió el regreso. A cuatro jornadas de marcha, Paikín se excusó de seguir a causa de un 
tumor en el muslo que le impedía andar a caballo. En una última junta de guerra, se resolvió retornar al fuerte del Río del Valle.

\section{A posteriori o después del tratado}

Casi tan pronto como se separó de la expedición, Paikín volvió a sus andanzas. En octubre de I774, el teniente de gobernador de Santa Fe, Francisco de la Riva Herrera, informaba a Vértiz, gobernador de Buenos Aires, que había recibido un pliego de Matorras en el cual le decía que el cacique pensaba atacar San Jerónimo, auxiliado por los indios reducidos en jurisdicción de Santa Fe. Las amenazas continuaron en diciembre y en el mismo mes se efectuaron los primeros robos. Además, Paikín procuró acercarse a aquella plaza. Según De la Riva Herrera, el cacique había insistido para tratar con él y reducirse en esa frontera. Pero el encuentro nunca se llevó a cabo (AGN, SF, S. IX 4-I-5).

Aunque los hispanocriollos pudieran no entenderlo, la dinámica relacional indígena marcaba las formas de ese juego. Dice Guilherme Felippe que, para el indio, el vínculo con el otro no podía pensarse en términos maniqueos de "bien" o "mal", que las relaciones no se establecían en la rigidez de tales extremos opuestos. Y algo semejante ocurría con la paz. La paz era una de las alternativas posibles para vincularse con los demás, pero no era necesariamente opuesta a la guerra. Y es que, aun cuando la paz se proyectara como algo distinto a dejar de hacer la guerra, aunque se concibiera como un horizonte posible y positivo para relacionarse con los otros, como planteó Bechis, esos otros no eran todos los otros. Si algo costaba entender a los religiosos y a las autoridades españolas era que, después de concertado un acuerdo, los enemigos de los hispanocriollos — indígenas o no- no pasaran inmediatamente a ser enemigos suyos. En cuanto forma posible - entre otras muchas - de relacionarse y no en cuanto idea capaz de pensarse como abstracción, la paz involucraba a las partes correspondidas en ese lazo, y por tanto tenía carácter personal. Los indios no hacían de ese vínculo una proyección que podía incluir a quienes fueran amigos o aliados de quien era la contraparte de esa paz. Lejos de ello, la paz podía convertirse en una estrategia que permitía sostener uno o más frentes de conflicto con destinatarios indígenas o hispanocriollos, diferentes de aquellos con quienes se establecía una concordia. Esa paz podía estar impulsada, incluso, por la necesidad de viabilizar enfrentamientos ancestrales, difíciles de mantener sin agregar un nuevo socio en el esquema. De ello se seguía que, en 
muchas ocasiones, estar en reducción no significara estar reducido. Por el contrario, como hizo Paikín, algunas agrupaciones se acercaban a pedir bautismo y pueblo para continuar con sus guerras, no para interrumpirlas. Las misiones, proveyendo ventajas estratégicas y materiales a los conflictos nativos, hacían posible que los indígenas persistieran en viejos enfrentamientos, e incluso acababan por fomentarlos (Felippe, "A cosmología" 97-99).

Además, la paz tampoco se pensaba como una relación capaz de sostenerse en el tiempo mientras las partes cumplieran lo acordado. La paz necesitaba una actualización constante, por medio de fiestas, encuentros, intercambios de obsequios o prestaciones, por ejemplo. De lo contrario, podía comenzar a debilitarse hasta devenir en otro vínculo, atravesando un sinfín de situaciones posibles de tensión, conflicto o enemistad.

Los hispanocriollos concebían la paz de un modo diferente. La paz era una idea situada en las antípodas de la guerra y, como extremo opuesto, la excluía. La paz se acordaba, se establecía, se pactaba, se celebraba y luego debía respetarse. Sin suprimir la posibilidad de su actualización periódica, su duración podía extenderse mientras las partes involucradas no la pusieran en riesgo rompiendo o incumpliendo los acuerdos básicos —explícitos o tácitos, próximos o lejanos en el tiempo- sobre los que se sostenía. Como idea susceptible de ser imaginada más allá de la contraparte implicada en el vínculo, para los blancos la paz suponía la incorporación de otros actores a las relaciones pacíficas, aunque no las hubieran pactado personalmente con los indígenas. De este lado, si Paikín había negociado la paz con Salta, no debía atacar la frontera de Santa Fe, y ello comprendía, por supuesto, a los abipones reducidos en San Jerónimo. Finalmente, cuando abarcaba a los indios como contraparte, para el hispanocriollo la paz incluía la posibilidad del sometimiento, a través, por ejemplo, de su incorporación a una reducción.

A comienzos de I776, en uno de los combates con Ychoalay, murió Paikín. Tras su deceso, arribó a Macapillo un grupo de jefes tobas y mocovíes que venían de mensajeros de los demás jefes del Chaco. Querían comunicarlo y hacer saber "[...] que no obstante su fallecimiento, los demás caciques se hallaban prontos a verificar las paces tratadas y establecidas con el Señor Don Gerónimo Matorras [...]”. Además, por su intermedio,

[...] la cacica viuda de dicho Paikín mandaba el bastón con que dicho Sr. Matorras había honrado a su difunto marido para que respecto de no ser sus hijos capaces de gobernar aquellas dilatadas naciones, lo 
colocase su Señoría en el cacique que fuese de su agrado [...] (AGN, $I$, ARAGN-So9-260I-0IO-0064, ff. 32/623)

La embajada no tenía únicamente esos móviles. Los indios sabían que también había dejado de existir Matorras. En ausencia de las partes contratantes, los mensajeros del Chaco se acercaban a Salta a mostrar su buena voluntad y saber "[...] si no embargante estos fallecimientos se hallaba el gobernador que hubiese sucedido en propósito de cumplir dichos tratados de paz y reducciones [...]" (AGN, I, ARAGN-So9-26oI-oio-0064, ff. 32/623 v. y r.). Como los que quedaron en el Chaco deseaban alguna comprobación de que los emisarios habían realizado su misión, Lapa se ofreció a volver con dichos jefes y evangelizar a los indígenas mientras permaneciera entre ellos.

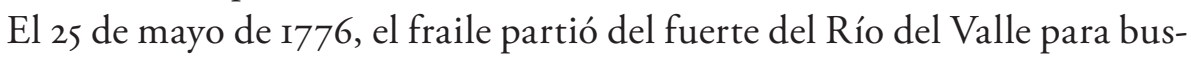
car a Queyavery, con el cometido de entregarle el bastón que antes se obsequiara a Paikín. Dice el religioso que los otros jefes explicaron "[...] que hallaban por conveniente que dicho Queyavery, como principal cacique y general de ellos pasase con otros cuatro jefes a la ciudad de Salta a dar las gracias al gobernador, y tratar despacio en asunto a Reducciones [...]" (AGN, I, ARAGN-So9-260I-OIO-0064, ff. 35/629). Lapa quedaría con sus familias aguardando el regreso.

La visita fue seguida de otras semejantes. De aquí al emplazamiento de las reducciones, comitivas de similar composición —en las que casi no se repiten los embajadores_-, se dirigieron a Salta a reiterar los pedidos y ratificar, una vez más, los acuerdos. Ello tenía que ver, sin duda, con el carácter personal que los indios atribuían a las relaciones, pero también con el hecho de que las alianzas no eran inmutables. Dice Pierre Clastres que, aun cuando aquellas pudieran suponerse durables, la traición era posible y frecuentemente real. Eso significa que la alianza no era un contrato, que su ruptura jamás era percibida como un escándalo y que una comunidad dada no tenía siempre los mismos aliados ni los mismos enemigos. El lugar del aliado era coyuntural y variable (207). Ser aliado, afirma Felippe, era una situación antes que una condición, era un estar antes que un ser ("A cosmologia" 99).

Para cuando partió Queyavery, el 22 de junio de 1776, Antonio Arriaga era el nuevo gobernador de Tucumán. El parlamento se llevó a cabo en su residencia. Entre varias preguntas que se hicieron, quiso saberse si los indios querían "[...] reducción en esta frontera [...] para con mayor puntualidad ser socorridos con cuanto necesiten [...]”. La respuesta indígena fue contundente: que ellos 
[...] desean y pretenden que se les establezca reducción en sus tierras para disfrutar de las comodidades que les proporcionan, pero que si $\mathrm{Su}$ Majestad no asintiese a esa súplica lo consultarán con sus parciales que quedaron en sus paises, cuya resolución manifestarán al Sr. Gobernador para que determine lo que hallare por conveniente [...] (AGN, I, ARAGNSog-26oi-oio-0064, ff. 56 v. y r. Énfasis añadido)

Esta vez en Salta, el cacique Queyavery y Antonio Arriaga asentaron nuevas paces por escrito. Se pactó que los indígenas debían mantener buena armonía con los grupos de todas las reducciones que rodeaban al Chaco. También se estableció que no habría muertes, robos ni irrupciones en las haciendas españolas de ninguna provincia. Se comprometían, a su vez, a avisar de cualquier ataque que las demás naciones quisieran hacer en las fronteras. Por último, los gobernadores de Tucumán, Paraguay y Buenos Aires se obligaban a mantener perpetuas paces con dichos caciques y sus parcialidades y a acompañarlos siempre que otros grupos les declararan la guerra (AGN, I, ARAGN So9-26oI-oio-0064, ff. 57 r. y 59 v.). Al igual que otros encuentros, este terminó con abrazos y la entrega de vestuarios y bastones a los jefes.

A mediados de 1776, dos años después del tratado celebrado entre Paikín y Matorras, las expectativas eran distintas. El empeño hispanocriollo en la sujeción a pueblo de los naturales cedía paso — al menos en el papel—al establecimiento de un vínculo más parecido a una alianza entre iguales, cuyo aspecto central era la mutua colaboración militar. Nada se estipuló en la letra sobre la reducción de los indios pese a que, según las actas del parlamento, el tema fue el eje de la conversación. El gobernador solo se comprometió a interceder ante el rey para obtener los recursos necesarios.

Cuando regresaron los emisarios de Salta y comunicaron los alcances de su misión, quedó claro que todavía se estaba lejos del fin deseado. Queyavery contó a Lapa que, ante la pregunta por los motivos de su visita, ellos respondieron que iban a ratificar las paces celebradas por Paikín, pero aclararon "[...] que la construcción de sus reducciones había de ser en sus mismas tierras [...]”. Sin embargo, en las actas del parlamento celebrado con Arriaga se dice otra cosa, y Lapa agrega que, según los jefes, era el gobernador quien "[...] consultaría con el rey, su amo [...]”, si los pueblos podían estar en el corazón del Chaco (AGN, I, ARAGN So9-26oI-OIO-0064, ff. 42/634 r. y 43/635 v.). Finalmente, nada se menciona en el diario de este sacerdote sobre las cuestiones incluidas en las nuevas paces que se habían convenido. 
Lapa, cumpliendo órdenes de Arriaga, debió volver a Macapillo. Nuevamente lo hizo acompañado por caciques, que además de escoltarlo querían ratificar las paces ahora selladas por Queyavery y hacer instancia al gobernador para que les mandara al fraile cuando el rey decidiese darles reducción. Pero esta vez Arriaga prescindiría del encuentro y delegaría en Agustín Zuviría el parlamento con ellos.

De las conversaciones sabemos poco. En el documento se observan idénticas preguntas que en la reunión entre Queyavery y Arriaga (AGN, I, ARAGN So9-260I-0Io-0064, ff. 6I/653 v.). Luego se leyeron las cláusulas del acuerdo precedente, que los caciques aceptaron. Se los instó a que en lo temporal reconocieran y reverenciaran al rey de Espańa y a quienes gobernaban en su nombre; y, por último, se les garantizó que el padre Lapa les sería puesto de doctrinero una vez erigida la reducción. A ello siguió la pregunta sobre la instalación del pueblo en la frontera, y, sorprendentemente, la respuesta consignada por quien escribe es una réplica de la que, al parecer, habían dado Queyavery y quienes se habían entrevistado con Arriaga el 30 de julio de 1776. Más aún, el acta que da cuenta de estas conversaciones es, a partir de aquí, una copia textual de la fechada cuatro meses atrás. Se agrega que los indios insistieron en que Lapa los acompañara a sus tierras, pero eso les fue negado hasta las resultas de su majestad. Resolvieron, entonces, que Sincimiagai — nieto del cacique Lachiquitínquedara en Macapillo para oficiar de chasque cuando llegara la licencia real.

Pasó más de un año. Andrés Mestre era el nuevo gobernador del Tucumán, Sincimiagai continuaba en la reducción y los parientes del indio no tenían ninguna novedad. Lachiquitín se acercó otra vez a Macapillo. Lapa escribió a Mestre, que parecía no estar al tanto de los compromisos asumidos por sus predecesores y pidió informes a Arriaga, quien reseñó los acontecimientos expuestos.

Mestre se dirigió al virrey Cevallos y le comunicó que Lachiquitín se había presentado con la determinación de llevarse a su nieto si no se le permitía que Lapa fuera con ellos. Adjuntaba a la nota una copia del diario escrito por el padre y agregaba que consideraba conveniente

[...] se les conceda la Reducción que desean, abriéndose paso por este medio a la navegación del Río Grande hasta Corrientes, que según me aseguran no es dificultoso desde donde pretenden establecerse en la orilla del mismo rio pues no quieren salir de sus tierras aunque se los he propuesto [...] (AGN, I, ARAGN So9-26oI-OIO-0064, ff. 72 v. y r. Énfasis añadido) 
Con las cartas de Mestre y de Lapa, su diario, el informe de Arriaga y otros papeles que se acumularon durante los años que el caso llevaba sin resolución, el expediente pasó al protector general de naturales, Gregorio Zamudio, y a Lorenzo Suárez de Cantillana, que debían analizarlo y pedir lo que resultara conveniente. Ambos coincidieron en la urgencia de atender el reclamo de los indígenas.

Después de ver el legajo, el abogado que hacía de fiscal lo remitió al Tribunal de Cuentas, que se expidió al cabo de un mes. Se consideraron utilísimas y ventajosas las nuevas reducciones de indios en los países del Gran Chaco, porque el rey las recomendaba. Así, el virrey podría llevar adelante el proyecto, ya que se le habían concedido amplias atribuciones al respecto9. El Tribunal de Cuentas proponía a Francisco Gabino Arias y Lorenzo Suárez de Cantillana como individuos apropiados para comenzar la obra (AGN, I, ARAGN So9-260I-0Io-0064, ff. I05-IO8).

El punto central del consenso estaba planteado. Todos los intervinientes evaluaron que debía darse comienzo a la edificación de los pueblos. Por eso, el virrey ordenó formar una junta "reduccional o de propaganda fide", que presidiría el gobernador de Tucumán. Esta se llevó a cabo en 1778 y arreglaría también los gastos que se hicieran, a quitarse del ramo de sisa. En caso de no alcanzar, se informaría al virrey y a su majestad para que proveyeran lo necesario. Se decidió realizar una expedición que construyera dos reducciones en el interior del Chaco. Serían emplazadas en la costa del río Grande, para mocovíes y tobas, "según se tenía pactado con Queyavery", siguiendo las paces establecidas con Paikín. Estarían bajo la inmediata autoridad del gobernador de Buenos Aires, por la cercanía que tendrían con la ciudad de Corrientes (AGN, I, ARAGN So9-260I-0Io-0064, ff. II6 v. y r.).

Las voces discordantes no tardaron en hacerse oír, pero el acuerdo sobre la fundación de los pueblos había ganado adeptos entre hombres suficientemente influyentes como para poner en marcha el proyecto. Juan José de Vértiz aprobó la campaña al Chaco. Para todo, confirió a Francisco Gabino Arias el título de comandante general de la empresa y a Suárez de Cantillana, el de superior $\mathrm{y}$ visitador general de las reducciones.

Ahora bien, ¿`cómo fue que la negociación iniciada y concluida en Salta, con distintos gobernadores de la capital tucumana, terminó con la edificación de dos reducciones en el interior del Chaco y, más aún, en jurisdicción de Buenos

9 Carlos III se lo ordenaba en una cédula del 6 de septiembre de 1777 (AGN, I, ARAGN So9-260I010-0064, ff. 86/681 a 101/696 r.). 
Aires? ¿Por qué Buenos Aires admitiría que las misiones se instalaran allí? Como dijimos al comienzo, la respuesta involucra las expectativas de los actores. En primer lugar, la presencia y la amenaza portuguesa en el área daban sentido a la instalación de dos pueblos con indios aliados, que marcaran el dominio español sobre un espacio difícil de controlar. Por otra parte, podía esperarse que reducir a tobas y mocovíes, hasta entonces infieles, limitara las agresiones que estos grupos cometían contra los abipones de San Jerónimo, auxiliados por sus parientes de San Pedro y San Javier, y amparados en su condición de enemigos. Simultáneamente, se interrumpiría la venganza abipona sobre los agresores. Cabe advertir que, en esa época, la frontera del Tucumán gozaba de cierta tranquilidad y su ocupación avanzaba hacia el este. La instalación de dos misiones en un área que libraba a Salta de su sostenimiento material haría posible, entretanto, la exploración del terreno, la navegación de los ríos y el aprovechamiento de nuevos vínculos y caminos comerciales con el litoral y el Atlántico. ¿Por qué los indios quisieron que las reducciones se edificaran ahí? El reclamo fue constante y desde sus inicios. Puede leerse en el tratado entre Matorras y Paikín, y aparece nuevamente en las conversaciones con Arriaga. En principio, Paikín y el resto de los emisarios querían permanecer en sus tierras, y rechazaban su reubicación en la frontera tucumana por lo que ello significaba material y simbólicamente. Pero además, en el marco de la reactivación económica que se acentuó hacia fines del siglo XviII, el Chaco se consolidó como un espacio de circulación del ganado vacuno, mular y de los cueros. A su vez, el tráfico de esclavos cobró importancia para el abastecimiento de las ciudades altoperuanas y también para el de los mercaderes portugueses. Los mocovíes de San Javier y San Pedro - y algún cura doctrinero- participaban en este circuito comercial. Las agrupaciones que habitaban el interior chaqueño también intervenían en esos intercambios y formaban parte de la puja por controlar lugares de tránsito, rutas comerciales, pasos estratégicos y determinados mercados. La reducción a orillas del Bermejo permitía mantener estas ventajas. Años después, lo confirmaba Miguel Gerónimo de Benavídez — hijo de Ychoalay-. Los mocovíes de Santa Fe, decía, asociados a grupos autónomos, continuaban robando en San Jerónimo. Luego "[...] permutan parte de nuestras caballadas, con las nuevas reducciones que se han establecido por los salteños, en la costa del Río Colorado de cuyos destinos, se transportan nuestros animales, hasta Salta [...]" (AGN, SF, S. IX 4-I-6). 


\section{Conclusiones}

En junio de I780, la campaña partía del fuerte del Río del Valle. Durante la marcha, Arias fue reuniéndose con diferentes caciques mocovíes y tobas que confirmaron sus intenciones de reducción. Las obras para edificar el pueblo de los últimos comenzaron en octubre, mientras que el otro estuvo listo a mediados del mes siguiente. La reducción de tobas se llamó San Bernardo el Vértiz, y Nuestra Señora de los Dolores y Santiago de Lacangayé la que se asignó a los mocovíes. En enero se designaron sus autoridades y, con el deber cumplido, el comandante y sus hombres se aprestaron a partir rumbo a Corrientes (Arias 4I-42).

En este trabajo analizamos la paz convenida entre algunos gobernadores del Tucumán y varios caciques tobas y mocovíes autónomos, para poder explicarla. Partimos de considerar que la construcción de esa paz fue un proceso relativamente largo, que excedió temporal y problemáticamente al tratado entre Matorras y Paikín. Iniciamos el análisis a comienzos de la década de 1770 y lo cerramos en 178I, con la construcción de las reducciones mencionadas. Sin embargo, retrocedimos en el tiempo para dar cuenta del devenir de las negociaciones.

Así, mostramos cómo y por qué fue instalándose la idea de la paz entre los indios y entre los hispanocriollos. Señalamos que la política borbónica hacia los indígenas y la llegada de Matorras a la gobernación del Tucumán marcaron un cambio en la forma de vinculación con los aborígenes. El proyecto de pacificación, que no descuidaba totalmente la evangelización, iba desplazando a las campañas punitivas y las entradas al Chaco. También explicamos cómo la presión de las tropas españolas a comienzos del siglo XviII dio lugar a un desplazamiento de los indios hacia nuevos territorios y modificó los lazos que trabaron con las fronteras. La aproximación de mocovíes, tobas y abipones a la jurisdicción de Santa Fe y Corrientes es ineludible para dar cuenta del proceso de paz que se gestó después en Salta. La guerra con los abipones de Ychoalay motivó el acercamiento de Paikín y sus coaligados a la capital tucumana en busca de aliados en sus enfrentamientos, un mercado donde ubicar los botines que pudieran obtenerse en ellos o en los ataques a otras fronteras, y la obtención de bienes y animales al incorporarse a la reducción, o en entregas posteriores.

El segundo momento estudiado fue el del parlamento y el tratado. Entonces exploramos el documento escrito, apoyándonos en una forma de aproximación diferente de las que se ocuparon del acuerdo en cuestión. Lejos de las interpretaciones de la historia del derecho o de cuestionar su interpretación como "dispositivos de etnificación y normalización", cruzamos el acta firmada con 
otra documentación que permitió obtener información escondida o distorsionada por los actores. Mostramos que la pluma no reflejó todo lo conversado, sino que ocultó cosas y deformó otras. Omitió, por ejemplo, el compromiso que asumió Matorras con los indios para que fueran desagraviados de los perjuicios recibidos de los abipones. El tratado también evitó referir a la insistencia de los indígenas en que se les dieran armas, se les enseñara a utilizarlas y se los auxiliara en sus enfrentamientos con Benavídez. Es que el escribiente ocultaba la poca disposición de Paikín a reconciliarse con aquel y evitaba mencionar los motivos que lo habían conducido a pedir la paz en la capital tucumana. Había que mostrar a Matorras como hábil negociador, gracias a cuya intervención se terminaba, simultáneamente, con los ataques a esa frontera y con los conflictos entre los indígenas, que repercutían en jurisdicción santafesina. Así, la tinta deformaba y en contrapartida devolvía una imagen trastocada de Paikín, a quien se mostraba amable, bien dispuesto y hasta sumiso. En esta parte incluimos, también, algunas consideraciones antropológicas sobre las negociaciones y el juego diplomático entre los indios.

Por último, el trabajo se detiene en los acontecimientos posteriores al acuerdo. Después de la muerte del "Gran Caporal” y de Matorras, las tratativas continuaron. Las comitivas indígenas regresaron a Salta una y otra vez, reclamando las reducciones prometidas. Las intenciones y las respuestas de los gobernadores fueron variando. Algunos prefirieron establecer acuerdos de convivencia pacífica y colaboración militar, como Arriaga. Las hostilidades de los indígenas del Chaco habían menguado. Los fuertes y las reducciones quedaban atrás de los particulares que, paulatinamente, avanzaban la ocupación hacia el este, y las haciendas continuaban creciendo. Entonces, las autoridades salteñas estaban más interesadas en ajustar la paz en nuevos términos que en cumplir las promesas hechas por Matorras. Pero no todas. Andrés Mestre ejecutó el proyecto. Consideraba conveniente conceder a los indios las reducciones que pedían. Hacerlo en sus tierras, sostenía, abriría paso a la navegación del Bermejo hasta Corrientes, y con ello a la exploración y circulación por el Chaco.

Este artículo también se ocupó del desplazamiento espacial implicado en las negociaciones: las tratativas iniciadas en Salta culminaron con el envío de una campaña que construyó dos pueblos en jurisdicción de Buenos Aires. Para explicarlo, incorporamos al análisis otras fronteras del Chaco meridional — como Santa Fe, Corrientes y, en menor medida, Asunción-. La propia movilidad indígena demandaba la inclusión de los espacios por los que se desplazaban y en los que establecían relaciones. Además, mostramos que el significado que 
cada una de las partes atribuyó a las reducciones en cuestión también explica tal corrimiento geográfico.

A las referidas intenciones de Paikín se agregaron otros factores. El Chaco se iba afianzando como espacio de circulación de los cueros y del ganado, respondiendo a la creciente reactivación económica de las últimas décadas del siglo XVIII. Además, el tráfico de esclavos para el abastecimiento del Alto Perú y los mercaderes portugueses cobraba creciente importancia. Los mocovíes de San Javier y San Pedro - y algún cura doctrinero- participaban en este circuito comercial. Las agrupaciones chaqueñas también intervenían en esos intercambios y pretendían controlar pasos estratégicos y hasta ciertos mercados. La instalación de los pueblos a orillas del Bermejo permitiría sostener esas ventajas. Así, la ubicación de sus reducciones nunca desapareció de las solicitudes de los indios.

Los hispanocriollos, por su parte, se mostraron reticentes en un primer momento, pero acabaron por aceptar tales reclamos. La razón, probablemente, se encuentre en la importancia de ese espacio como atajo en la comunicación de las ciudades entre sí y con Potosí, y en la oportunidad de explorar y abrir nuevas rutas comerciales que lo atravesaran sin riesgos. Pero, también, en la posibilidad de asentar allí la presencia española, para limitar el peligro del avance portugués. Así que Nuestra Señora de los Dolores y Santiago de Lacangayé, y San Bernardo el Vértiz quedaron en jurisdicción de Buenos Aires. Ambas estaban a solo 60 leguas de Corrientes, mientras que más de 200 las separaban de Salta. 


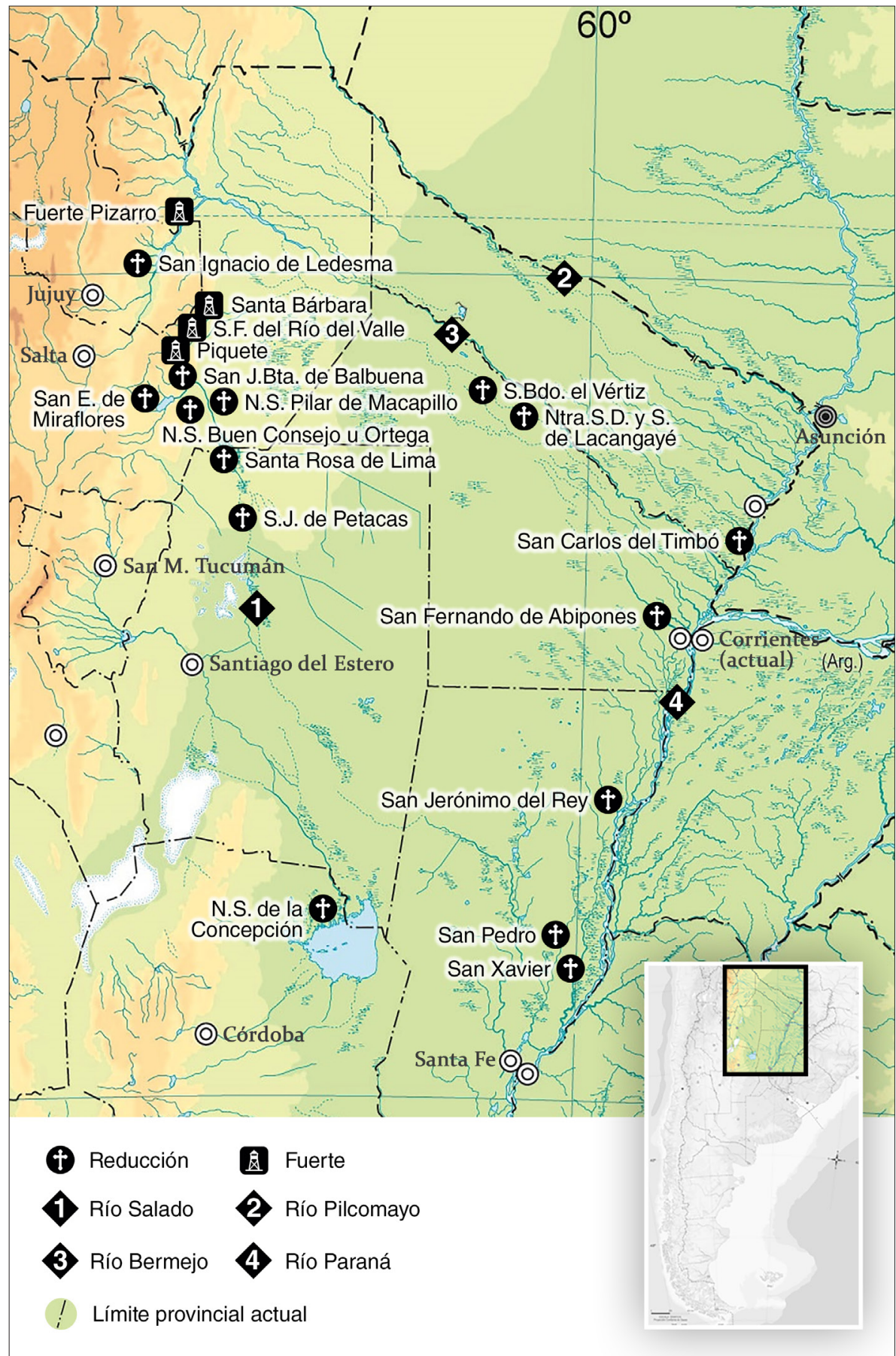

$\rightarrow$ FIGURA I

Algunas reducciones y fuertes del Chaco hacia fines del siglo XVIII Fuente: elaboración propia con base en Maeder; Mata. 


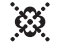 \\ B I B L I O G R A F í A}

\section{F U E N T ES PR I M A R I S}

\section{A. Archivos}

Archivo General de la Nación, Buenos Aires, Argentina (AGN).

Fondo de Gobierno Colonial.

Interior (I) ARAGN-So9-2601-010-0064.

Santa Fe (SF), sala (s) IX 4-1-5 y IX 4-1-6.

Tribunales (T), sala (s) IX 37-6-2.

Archivo General de la Provincia de Santa Fe, Argentina (AgPSF).

Actas del Cabildo de Santa Fe (ACSF).

https://www.santafe.gob.ar/actascabildo.

Archivo Histórico de la Provincia de Jujuy, San Salvador de Jujuy,

Argentina (AHPJ).

Libros Capitulares $(L C)$.

Colección Ricardo Rojas (CRR), t. XxviII.

Archivo de los Tribunales de San Salvador de Jujuy, Argentina (ATJ).

Leg. I5I5, año I77I.

\section{B. Impresos}

Arias, Francisco G. "Diario de la Expedición Reduccional del año de I780 mandada a practicar por orden del Virrey de Buenos Aires a cargo de su ministro Francisco Gabino Arias, Coronel del Regimiento de Caballería, San Fernando". Angelis, pp. 3-50.

Brizuela, Blas Joaquín de. "Diario de la expedición hecha en I774 a los países del Gran Chaco desde el Fuerte del Valle por D. Gerónimo de Matorras, gobernador del Tucumán”. Angelis, pp. 4-33.

\section{F U E N T ES S E C U N D A R I A S}

Angelis, Pedro de, editor. Colección de obras y documentos relativos a la historia antigua y moderna de las provincias del Rio de la Plata, t. vi. Buenos Aires: Imprenta del Estado, 1837 . 
Assadourian, Carlos, Guillermo Beato y José Carlos Chiaramonte. De la Conquista a la Independencia, vol. 2 de Colección Historia Argentina. Buenos Aires: Paidós, 2010.

Bechis, Martha. "Pensar la paz: pampas, serranos, puelches y aucas a propósito del tratado de paz entre la gobernación de Buenos Aires y el cacique tehuelcheserrano Cangapol (1740-1742)". Piezas de etnohistoria del sud sudamericano. Madrid: Consejo Superior de Investigaciones Científicas, 2008, pp. 8I-II3.

Cervera, Manuel. Historia de la ciudad y provincia de Santa Fe, 1573-1853. Santa Fe: R. Ibáñez, I908.

Clastres, Pierre. Arqueología de la violencia: la guerra en las sociedades primitivas. Buenos Aires: Fondo de Cultura Económica, 2004.

Felippe, Guilherme G. "A cosmologia construída de fora: A relaçâo com o outro como forma de produçâo social entre os grupos chaquenhos no século I8". Tesis doctoral en Historia. Universidade do Vale do Rio Dos Sinos, 2013.

Godelier, Maurice. El enigma del don. Barcelona: España, I998.

Gullón Abao, Alberto. La frontera del Chaco en la gobernación del Tucumán, I750-I8ro. Cádiz: Servicio de Publicaciones Universidad de Cádiz, 1993.

Kersten, Ludwig. Las tribus indigenas del Gran Chaco hasta fines del siglo XVIII. Resistencia: Universidad Nacional del Nordeste, I968.

Lázaro Ávila, Carlos. "Conquista, control y convicción: el papel de los parlamentos indígenas en México, el Chaco y Norteamérica”. Revista de Indias, vol. Lix, n. ${ }^{\circ}$ 217, I999, pp. 645-673. https://doi.org/Io.3989/revindias.I999.i217.831.

Levaggi, Abelardo. Paz en la frontera. Historia de las relaciones diplomáticas con las comunidades indigenas en la Argentina (siglos XVI-XIX). Buenos Aires: Universidad del Museo Social Argentino, 2000.

Lucaioli, Carina. Abipones en las fronteras del Chaco. Una etnografía bistórica sobre el siglo XVIII. Buenos Aires: Sociedad Argentina de Antropología, 2orr.

---. "Alianzas y estrategias de los líderes indígenas abipones en un espacio fronterizo colonial (Chaco, siglo xvinI)". Revista Española de Antropología Americana, vol. 39, n. ${ }^{\circ}$ I, 2009, pp. 77-96.

Lucaioli, Carina y Florencia Nesis. "El ganado vacuno de los grupos abipones y mocoví en el marco de las reducciones jesuíticas, I743-1767”. Andes, n. ${ }^{\circ}$ 18, 2007, pp. I29-152.

Maeder, Ernesto. "La iglesia misional y la evangelización del mundo indígena”. Nueva Historia de la Nación Argentina, vol. II. Buenos Aires: Planeta, 1999, pp. 433-468. 
Mata de López, Sara. "Las fronteras coloniales como espacios de interacción social. Salta del Tucumán (Argentina), entre la Colonia y la Independencia”. Dimensión Antropológica, año I2, vol. 33, enero-abril, 2005, pp. 69-9o.

Nacuzzi, Lidia. "Los grupos nómades de la Patagonia y el Chaco en el siglo xviı: identidades, espacios, movimientos y recursos económicos ante la situación de contacto”. Chungará (Arica), vol. 39, n. ${ }^{\circ}$ 2, 2007, pp. 22I-224. http://dx.doi. org/I0.4067/So717-73562007000200005.

---."Tratados de Paz, grupos étnicos y territorios en disputa a fines del siglo xvirı”. Investigaciones Sociales, vol. Io, n. ${ }^{\circ}$ I7, 2006, pp. 435-456.

Nesis, Florencia. "El camino de Paikín: un acercamiento a los grupos mocoví del Chaco a través del tratado de I774”. Avá (Posadas), n. ${ }^{\circ}$ I3, 2008, s. p.

---. Los grupos mocovi en el siglo XVIII. Buenos Aires: Sociedad Argentina de Antropología, 2005 .

Paz, Gustavo y Gabriela Sica. "La frontera oriental del Tucumán en el Río de la Plata (siglos XVI-XVIII)”. Las fronteras en el mundo atlántico, editado por Emir Reitano y Susana Truchuelo. La Plata: Universidad Nacional de La Plata, Facultad de Humanidades y Ciencias de la Educación, 20I7, pp. 293-330.

Roulet, Florencia. "Con la pluma y la palabra. El lado oscuro de las negociaciones de paz entre españoles e indígenas”. Revista de Indias, vol. 64, n. ${ }^{\circ} 23 \mathrm{I}, 2004$. https:// doi.org/Io.3989/revindias.2004.i23I.543.

Saeger, James. The Chaco Mission Frontier. The Guaycuruan Experience. Tucson: The University of Arizona Press, 2000.

Vitar, Beatriz. Guerra y misiones en la frontera chaqueña del Tucumán (I700-I767). Madrid: Consejo Superior de Investigaciones Científicas, I997.

Weber, David. Bárbaros. Los españoles y sus salvajes en la era de la Ilustración. Barcelona: Crítica, 2007.

---. "Borbones y bárbaros. Centro y periferia en la reformulación de la política de España hacia los indígenas no sometidos”. Anuario IEHS, n. ${ }^{\circ}$ I3, I998, pp. I47-I7I. 